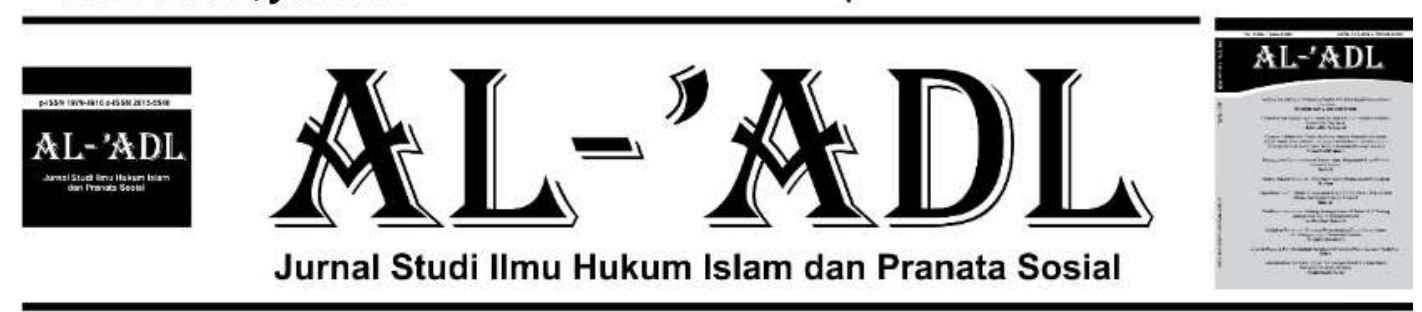

journal homepage : ejournal.iainkendari.ac.id/al-adl

The Effectiveness of Election Administrative Law Enforcement by the General Election Supervisory Agency

\title{
Bahari $^{1}$, Laode Bariun ${ }^{2}$, Winner Agustinus Siregar ${ }^{3}$
}

${ }^{1}$ Program Studi Magister Hukum, Pascasarjana, Universitas Sulawesi Tenggara, Indonesia

${ }^{2}$ Program Studi Magister Hukum, Pascasarjana, Universitas Sulawesi Tenggara, Indonesia

${ }^{3}$ Program Studi Magister Hukum, Pascasarjana, Universitas Sulawesi Tenggara, Indonesia

Email: bahariari2000@gmail.com ${ }^{1}, 1 \mathrm{~m}$ bariun@yahoo.co.id ${ }^{2}$, wasiregar@gmail.com ${ }^{3}$

\section{ARTICLE INFO}

Article History:

Received: 2021-05-05

Accepted: 2021-05-06

Published: 2021-07-31

Keywords :

Administrative Law, Bawaslu, Effectiveness, General Election

(C) 2021 Al-'Adl. All rights reserved

\begin{tabular}{l} 
ABSTRACT \\
\hline This research examines the the effectiveness of \\
election administration law enforcement by the \\
General Election Supervisory Agency in the \\
application of Law no. 7 of 2017 concerning \\
Elections related to handling violations, namely \\
Article 461 paragraph 6 and Article 464 of Law \\
Number 7 of 2017 in handling administrative \\
violations in the 2019 Election at Southeast Sulawesi. \\
With the various forms of Administrative Election \\
violations found in the 2019 General Election, it \\
takes hard work from the Election Supervisory \\
Agency (Bawaslu) to handle administrative violations \\
in order to create the 2019 Election that is fair, \\
honest, and free of various kinds of violation. The \\
method of this research uses empirical normative \\
legal research with a statue approach. The results \\
showed that administrative violations processed by \\
\hline
\end{tabular}


Bawaslu of Southeast Sulawesi Province reflect the effectiveness of the application of Article 461 paragraph 6 and Article 464 of Law Number 7 of 2017 in handling administrative violations in the 2019 Election at Southeast Sulawesi. Bawaslu of Southeast Sulawesi Province has handled 5 (five) administrative violations with verdicts that do not meet the formal and material requirements, 2 (two) administrative violations with a verdict not proven legally and a verdict proven legally. This achievement is an effective performance of making verdict that lead to doing things right, which contributes to fulfill mission or achieve goals of agency. The violation was caused by the reported party's unconsciousness that it qualifies as a violation and the reported lack of awareness in implementing direct, general, free, confidential, honest and fair in the administration of elections. From the aspect of legal culture, the general public or the parties misunderstand that their actions are classified as violatios in election.

\section{A. Introduction}

After the New Order era, the demands of democracy activists regarding the establishment of an independent general election organizer (Pemilu) became increasingly strong. This demand arose based on the experience that in the elections of the New Order occured systematic frauds by the organizers so that the elections in the New Order era had lost public trust. One of the main responses to this fraud was the emergence of the White Group (Golput). Golput is a direct representation of disillusionment to the Golongan Karya Party (Golkar), a new force that is expected to bring a change but acts fraudulently to perpetuate its power. The 1971 election which was the first general election in the New Order era was attended by 10 (ten) contestants and Golkar won $62.83 \%$ of the vote ${ }^{1}$. In the 1977 elections, a party fusion policy was applied so that the election participants became 3 (three) namely

${ }^{1}$ Harun Husein, 2014, Pemilu Indonesia; Fakta, Angka, Analis, dan Studi Banding, Perludem Jakarta, p. 600. 
Persatuan Pembangunan Party (PPP), Demokrasi Indonesia Party (PDI) and Golongan Karya Party².

The 1977 elections were "colored" by a number of massive frauds that resulted protests from Persatuan Pembangunan Party (PPP), Demokrasi Indonesia Party (PDI), students and national figures. The government then revised the electoral rules, namely Law Number 2 of 1980 concerning Amendments to Law Number 15 of 1969 concerning the General Election of Members of the People's Consultative Assembly/People's Representative as amended by Law Number 4 of $1975^{3}$. The legislation states that first: elements of Political Parties and Golkar are members of the election committee from the center to the sub-districts called the Indonesian Election Committee (PPI), Level I Regional Election Committee (PPD I), Level II Regional Election Committee (PPD II) and the Voting Committee (PPS). Second: The establishment of a new institution to oversee elections is called the Election Monitoring Committee (Panwaslak). However, the changes in the rules have actually positioned the election management Agency as a tool for the rulers to maintain their political power.

Election management remains the responsibility of the Ministry of Home Affairs, so that strategic positions in election management institutions are ex officio held by the Minister of Home Affairs and Regional Heads. Although there are representatives of election participants, they are only symbolic. Likewise, the Election Supervisory Agency from the central level to the regional level is held ex officio by the Attorney General, the Head of the High Prosecutor's Office, and the Head of the District Attorney's Office. In the lowest election committee structure that interacts with voters, namely the Voting Organizing Group (KPPS), there are no elements outside the government involved ${ }^{4}$.

Election management institutions during the New Order era were considered to have experienced systematic dysfunction. Elections during the New Order era judged by a number of political observers unfulfilled criteria as democratic elections. Elections in Indonesia during the New Order era became

${ }^{2}$ Ibid., p. 601 .

${ }^{3}$ Ibid., p. 602.

${ }^{4} I$ Ibid., p. 602-603. 
a tool for the interests of the New Order political machine to strengthen the legitimacy of the power of President Soeharto's government ${ }^{5}$.

According to R. William Liddle, quoted by Topo Santoso, et al, in the book "Election Law Enforcement" in the political engineering of the New Order Elections, this was carried out with a number of strategies, namely, first, the widespread use of the power to appoint (without following the election process) members of the legislature from the military groups, regional representatives, and other community groups deemed by the President to be unrepresented in the DPR. Second, form the Golongan Karya (Golkar) as a mass organization that can participate in general elections other than political parties. The existence of Golkar was then organized by the New Order Government as a political machine to always win elections among others, by the implementation of the monoloyalty policy of bureaucratic employees to Golkar. In addition, the government's policy of utilizing the bureaucratic structure and security forces to control the general election institutions and oversee the running of the election suppresses the movement of political parties during the election, resulting in a striking Golkar victory ${ }^{6}$.

If it is reviewed further, the position and function of the General Elections Implementation Supervisory Committee (Panwaslak Election) in the committee structure is not clear. The first role is to oversee the implementation of the election, but the other role is to be responsible to the chairman of the election committee according to its level. The Election Supervisory Committee is subordinate to the election executive committee. The organizational structure and its structure had the aim of controlling the implementation of the election. The supervisory function by the Election Panwaslak was misused for the benefit of Golkar with legalizing cases of violations and fraud committed by Golkar, besides that the Panwaslak discriminated with investigating cases committed by non-Golkar election participants ${ }^{7}$.

Entering the reform era, there was a fundamental change of the system and institutional arrangements in political life in Indonesia, including changes to the institutional order of election organizers. The 1945 Constitution of the Republic of Indonesia Article 22E paragraph (5) states that "Election is held by an election management agency that is national, permanent, and independent".

${ }^{5}$ Achmad Fachrudin, 2013, Jalan Terjal Munuju Pemilu 2014: Mengawasi Pemilu Memperkuat Demokrasi, Gramedia Utama Publishindo, Jakarta, p. 17.

${ }^{6}$ Topo Santoso et al, 2014, Penegakan Hukum Pemilu, Perludem, Jakarta, p. 37 - 38.

${ }^{7}$ Ibid., p. 39. 
National in nature means that the implementation of the General Election covers the entire Territory of the Republic of Indonesia. Permanent in nature means that the election management agency carries out its duties on an ongoing basis, even though its membership is limited by a certain period of time. Independent in nature means that in carrying out the General Election, the Election organizer is independent and free from the influence of any party, and has clear responsibilities in accordance with the legislation.

Article 22E paragraph (5) of the 1945 Constitution becomes the basis for the establishment of an independent general election organizer. The government then implemented the mandate of Article 22E paragraph (5) of the 1945 Constitution by stipulating a law that regulates Election Organizers specifically, namely Law Number 3 of 1999 concerning General Elections which is better than the previous law in regulating the implementation of democratic elections. In fact, although based on reports from election observers and the mass media, there were far more cases of fraud in the 1999 election handled. However, referring to the Central Panwaslu report for the 1999 General Election, it can be seen that the institution was only able to resolve cases of administrative violations, while violations involving election crimes, including money politics, were not handled properly. A total of 270 (two hundred and seventy) cases of election criminal offenses were transferred to the police, but only 26 (twenty six) were processed until the court. For money politics cases, none of them were processed until the court, although the indications were very strong and became a public issue ${ }^{8}$.

The conditions of organizing the General Election underwent a change after the third amendment to the 1945 Constitution which was ratified in the General Session of the People's Consultative Assembly in November 2001. The laws and regulations derived from the amendments are Law No. 12 of 2003 concerning General Elections for Members of the House of Representatives, Regional Representatives Council, and the Regional People's Representative Council, and Law No. 23 of 2003 concerning the General Election of the President and Vice President. These two legal bases made the performance of the Election Supervisors in 2004 better than the previous elections ${ }^{9}$.

\footnotetext{
${ }^{8}$ Ibid., p. $49-50$.

${ }^{9}$ Ibid., p. 51.
} 
In the 2004 legislative elections, there were 8013 (eight thousand thirteen) cases of administrative violations but only 2822 (two thousand eight hundred and twenty two) cases were resolved by the General Election Commission/Regional General Election Commission. For criminal offenses, out of 2413 (two thousand four hundred thirteen) cases that were delegated, only 1065 (one thousand sixty five) cases were successfully tried. There were 644 (six hundred forty-four) dispute cases received by the election supervisors, 380 (three hundred and eighty) were resolved by deliberation, 33 (thirty three) were resolved alternatively and 61 (sixty-one) until a final verdict was made. Meanwhile, in the 2004 Presidential and Vice-Presidential Election, out of 1158 (one thousand one hundred and fifty-eight) administrative violation cases, only 259 (two hundred and fifty-nine) were resolved. There were 274 (two hundred and seventy-four) cases of criminal offenses that were successfully forwarded as many as 187 (one hundred and eighty-seven) but only 82 (eighty-two) reached the court and 79 (seventy-nine) received a verdict. For disputes, there are 43 (forty three) cases received, 33 (thirty three) resolved by deliberation, 6 (six) cases through alternative methods and 2 (two) cases until the final verdict. ${ }^{10}$

The Election Supervisory Agency of Southeast Sulawesi Province (Bawaslu Sultra) is an election organizing agency tasked with supervising the implementation of general elections in the entire region of Southeast Sulawesi Province. The Bawaslu Sultra oversees 15 regencies and 2 cities, namely Kab. Konawe, South Konawe, North Konawe, Konawe Islands, Kolaka, East Kolaka, North Kolaka, Bombana, Buton, South Buton, North Buton, Central Buton, Wakatobi, Muna and West Muna as well as Kendari City and Bau-Bau City.

The Southeast Sulawesi Bawaslu carries out thorough supervision at every stage of the 2019 general election. The comprehensive supervision in question covers all stages of the election, starting from the stages of updating voter data, verifying political parties, nominating members of DPD, Provincial DPRD, supervising the procurement and distribution of voting equipment and vote counting, campaign stages, polling and counting, campaign funds, and vote recapitulation as well as supervision of the neutrality of the State Civil Apparatus (ASN), the neutrality of members of the Indonesian National Armed Forces (TNI), and the neutrality of members of the Indonesian National Police.

${ }^{10}$ Ibid., p. $52-62$. 
In organizing the 2019 election stages in Southeast Sulawesi, there were several findings at the stages of updating data and voter lists, procurement and distribution of voting equipment and vote counting, but these findings were immediately followed up in the form of recommendations and improvements at that time. Meanwhile, at the campaign stage, there were findings of alleged violations which were followed up by the handling mechanism of election violations.

In terms of the application of Law no. 7 of 2017 concerning Elections related to handling violations, namely Article 461 paragraph 6 which reads the verdicts of Bawaslu, Provincial Bawaslu, Regency/Municipal Bawaslu to resolve election administration violations in the form of: a. administrative improvement of the procedures, procedures, or mechanisms in accordance with the provisions of the legislation; b. written warning; c. are not included in certain stages in the Organizing of Elections; and D. other administrative sanctions in accordance with the provisions of this Law. Article 464 states that in the event that KPU, Provincial KPU, Regency/Municipal KPU, PPK, PPS, or Election Contestants unfollow up on the verdicts of Bawaslu, Provincial Bawaslu, and Regency/Municipal Bawaslu, therefore Bawaslu, Provincial Bawaslu, and Regency/Municipal Bawaslu propose complaint to DKPP. In this case, if the KPU is found guilty laterbut implements the Bawaslu verdict, it can not be repoted to DKKP because it has fulfilled the provisions of Law no. 7 of 2017. With the various forms of Administrative Election violations found in the 2019 General Election, it takes hard work from the Election Supervisory Agency (Bawaslu) to handle administrative violations in order to create a 2019 Election that is fair, honest, and free of various kinds of violation. Based on the background of the problems related to election administrative violations which will be investigated entitled "EFFECTIVENESS OF ELECTION ADMINISTRATION LAW ENFORCEMENT BY THE GENERAL ELECTION SUPERVISORY AGENCY (Study on Handling Election Administration Violations in Bawaslu of Southeast Sulawesi Province for the 2019 Election)"

\section{B. Method}

The type of research/approach used by the author is empirical normative legal research. Normative legal research according to Peter Mahmud Marzuki is legal research conducted with a statute approach, a case approach, a historical approach, a comparative approach, and a conceptual approach, while 
normative empirical, namely juridical research is carried out by examining library materials which are primary data and also called library research. Empirical legal research is carried out by researching the field which is a secondary legal material.

The type of approach method in this study uses a juridical-empirical approach, namely the statue Approach and the Case Approach. This research includes empirical juridical legal research, so the types of sources of legal materials used are primary sources of legal materials and secondary sources of legal materials.

Data collection methods were collected through inventory procedures and identification of laws and regulations, as well as classification and systematization of data in accordance with research problems. The results obtained through literature study and interviews are arranged systematically and analyzed in accordance with the empirical normative approach. The approach used is descriptive qualitative analysis, namely analysis with efforts to find principles and theories in analyzing problems in research.

\section{Results and Discussion}

\section{The Role of Southeast Sulawesi Bawaslu in Supervision of Administrative Violations in the 2019 Election}

The legal position of Bawaslu in supervising the stages of the General Election is stated in Article 89 of Law Number 7 of 2017 concerning General Elections, "Supervision of the implementation of General Elections is carried out by Bawaslu". Based on their position, with respect to this function, some experts still group them within the scope of executive power or in a new power group, namely the fourth branch of the government as stated by Yves Mene and Andrew Knapp as follows:

"Regulatory and monitoring bodies are a newtype of autonomous administration wihich has been most widely developed in the United States (where it is sometimes referred to asthe 'headless fourth branch' of thegovernement). It takes the form of what aregenerally known as Independent Regulatory Commissions."

Regulatory and monitoring bodies are a new type of autonomous government that has been most developed in the United States (where it is sometimes referred to as the 'headless fourth branch' of government). This takes the form commonly known as an independent regulatory commission. 
According to Yves Meng and Andrew Knapp, there is a fourth power, namely Independent institutions. According to Yves Meng and Andrew Knapp, these institutions exist because of the tendency in administrative theory to shift regulatory and administrative tasks into the tasks of independent institutions.

Bawaslu has an authorized source by laws and regulations, namely Law No. 7 of 2017 concerning General Elections which is obliged to carry out its authority. Indonesia as a state of law is stated in article 1 paragraph 3 of the 1945 Constitution of the Republic of Indonesia. The concept of "Indonesia is a state of law" explains that all the authority and actions of state equipment or authorities are solely based on law or in other words regulated by law. The Indonesian legal state that uses a system of separation of powers between the legislature, executive and judiciary is aimed at protecting human rights by separating the legislators, implementing regulations and adjudicating them not in one hand.

The nature of Bawaslu's authority is attribution The nature of bawaslu authority is attribution which is the power of the Government or government authority directly granted by the Law. H. D. Van Wijk in Ridwan H.R stated that

"Atributie: toekenning van een bestuur bevoegdheid toekenningdoor een wetgever aan een bestuursorgaan"

(Attribution is the granting of government authority by lawmakers to government organs.)

Furthermore, H. D. Van Wijk suggested that lawmakers create a government authority and submit it to a Government agency. The authority to supervise the stages carried out by Bawaslu is divided into 2, namely based on Article 97 letter b of Law Number 7 of 2017 concerning General Elections. Bawaslu is in charge of overseeing the stages of organizing elections in the province. In exercising the authority to supervise at each stage of the implementation of the General Election, based on Article 100 of Law Number 7 of 2017 concerning General Elections, the Provincial Bawaslu is obliged to "be fair in carrying out its duties and authorities". As a follow-up to Law Number 7 of 2017 concerning General Elections, the General Election Supervisory Agency Regulation (Perbawaslu) Number 21 of 2018 concerning Supervision of the Implementation of General Elections which explicitly and lex specialis outlines the procedures for supervising the implementation of general elections. 
Based on Article 1 point 6 of Perbawaslu Number 21 of 2018 concerning Supervision of the Implementation of Elections, "Provincial Bawaslu is the Agency that oversees the implementation of elections in the Province". Provincial Bawaslu supervises:

a. Stages of holding elections in the province;

b. Following up on findings and reports of election violations;

c. Implementation of follow-up to the recommendations of the Election Supervisor;

d. Implementation of verdicts / verdicts in the province.

Based on Article number 3 of Perbawaslu Number 21 of 2018 concerning Supervision of Election Implementation, "The implementation of supervision is carried out directly by ensuring that all stages of the election are carried out in accordance with the provisions of the legislation". In carrying out the function of supervising authority, Bawaslu can work together with the community to increase public participation in every stage of the election administration to realize a fair-judicial election.

Based on Article 13 of Perbawaslu Number 21 of 2018 concerning Supervision of Election Implementation, "Election Supervisors in carrying out supervision of Election Implementation involve the participation of related parties which are carried out by: a. Coordination with related agencies or institutions; or b. Collaboration with community groups."

The supervisory activity carried out by Bawaslu is to oversee the process of the democratic election party in accordance with the expected results. Every activity related to supervision, whether it is following up on findings of election violations, must have a fullow up or evaluation. With this evaluation, it can be seen the weaknesses that form the basis for the possible lack of participation in terms of member participation, motivation and so on. This activity is a corrective action on problems encountered in the field to be followed up. This is intended so that in the future the same mistakes will not be repeated on the same object. ${ }^{11}$

One of the efforts of the Bawaslu of Southeast Sulawesi Province in carrying out supervisory function is to organize a community participatory supervision center, namely the involvement of the community in election supervision is carried out through the socialization process, transfer of

${ }^{11}$ Abdul Wahid, "Meneguhkan Bawaslu sebagai Lembaga Peradilan dalam Bingkai Pengawasan Pemilu”, Jurnal Adhyasta Pemilu, Vol. 4 No. 1, 2018, p. 65. 
knowledge on elections and dignity, as well as provide a role to the community to collaborate with election supervisors in the agenda of monitoring elections and prevention of election violations, in any room, any time. To encourage community participation and increase the collaboration of the Southeast Sulawesi Province Bawaslu with civil society, these activities include:

a. In addition to carrying out supervisory activities to increase public participation, Bawaslu is also given the authority to supervise the stages of the implementation of the General Election directly, which is mandated by Article 1 number 25, Article 2, and Article 4 of Perbawaslu Number 7 of 2017 concerning the handling of findings and reports of election violations, Article 6, Article 7 and Article 8 of Perbawaslu Number 21 of 2018 concerning Supervision of Election Implementation in Article 89, Article 100 of Law Number 7 of 2017 concerning General Elections.

b. In addition to carrying out supervisory activities to increase public participation, Bawaslu is also given the authority to directly supervise the stages of the implementation of the General Election, which is mandated by Article 1 number 25, Article 2, and Article 4 of Perbawaslu Number 7 of 2017 concerning the handling of findings and reports of election violations, Article 6, Article 7 and Article 8 of Perbawaslu Number 21 of 2018 concerning Supervision of Election Implementation in Article 89, Article 100 of Law Number 7 of 2017 concerning General Elections.

c. In carrying out the supervisory function during the election process, Election Supervisors can carry out direct supervision, by coming directly at the place/event to be monitored. For example, at the election campaign stage, one of the candidates holds a general meeting to attract sympathizers. Thus, election supervisors can ensure that there are no alleged violations at the time of the general meeting by coming to supervise the campaign site for the general meeting directly.

d. Election supervisors can also conduct indirect supervision. In carrying out its supervisory functions, indirect supervision is one of the supervisory activities carried out by conducting deeper research or examination, auditing documents or administrative processes carried out during the selection stage. For example, an examination of the Official Report attached by the KPU, research on campaign finance documents 
that were examined by an audit agency appointed by the KPU. However, in carrying out the authority to oversee the stages of organizing the Election, the Southeast Sulawesi Province Bawaslu experienced several obstacles in terms of the quantity of human resources and inadequate equipment.

e. In exercising its authority to oversee the implementation of elections, the Southeast Sulawesi Province Bawaslu handles the findings carried out by election supervisors based on their level. The following table showeds the findings of election violations handled by the Southeast Sulawesi Province Bawaslu.

\section{Effectiveness of Application of Article 461 Paragraph 6 and Article 464} of Law No. 7 of 2017 concerning Elections Related to Sanctions for Administrative Violations of Elections in 2019 In Southeast Sulawesi

The Election Supervisory Agency for Southeast Sulawesi Province (Bawaslu Sultra) oversees the implementation of general elections in the entire region of the Southeast Sulawesi Province. The Southeast Sulawesi Bawaslu oversees 15 regencies and 2 cities, namely Kab. Konawe, South Konawe, North Konawe, Konawe Islands, Kolaka, East Kolaka, North Kolaka, Bombana, Buton, South Buton, North Buton, Central Buton, Wakatobi, Muna and West Muna as well as Kendari City and Bau-Bau City.

In organizing the 2019 election stage in Southeast Sulawesi, there were several findings at the stage of updating data and voter lists, procurement and distribution of voting equipment and voting equipment. But these findings were immediately followed up in the form of recommendations and improvements on the spot. While at the campaign stage, there were findings of alleged violations which were followed up through the mechanism for handling election violations. It will be seen how effective the implementation of Article 461 paragraph 6 and Article 464 of Law Number 7 of 2017 concerning General Elections relates to sanctions for administrative violations of the 2019 Election in Southeast Sulawesi.

In the application of Law no. 7 of 2017 concerning Elections related to handling violations, namely Article 461 paragraph 6 which reads the verdicts of Bawaslu, Provincial Bawaslu, Regency/Municipal Bawaslu to resolve election administration violations in the form of: a. administrative improvement of the procedures, procedures, or mechanisms in accordance 
with the provisions of the legislation; b. written warning; c. are not included at certain stages in the Organizing of Elections; and d. other administrative sanctions in accordance with the provisions of this Law.

Article 464 states that in the event that KPU, Provincial KPU, Regency/Municipal KPU, PPK, PPS, or Election Contestants unfollow up on the verdicts of Bawaslu, Provincial Bawaslu, and Regency/Municipal Bawaslu, then Bawaslu, Provincial Bawaslu, and Regency/Municipal Bawaslu make a complaint to DKPP. In this case, if the KPU is later proven guilty but implements the Bawaslu verdict, it cannot be reported to the DKPP because it has complied with the provisions of Law no. 7 of 2017. With the various forms of Administrative Election violations found in the 2019 General Election, it takes hard work from the Election Supervisory Agency (Bawaslu) to handle administrative violations in order to create a 2019 Election that is fair, honest, and clean of various kinds of violation.

To analyze and determine the implementation of election supervision by the Election Supervisory Committee of Southeast Sulawesi Province was carried out effectively or not, it will first be explained about the perspective that will be used to assess the effectiveness of Election supervision by the Election Supervisory Committee of Southeast Sulawesi Province. Lawrence M. Friedman argues that the effectiveness and success of law enforcement depends on three elements of the legal system, namely the legal structure, legal substance and legal culture. The legal structure concerns law enforcement officers, legal substance includes statutory instruments and legal culture is a living law adopted in a society. Based on the above description and referring to the legal system theory, specifically the effectiveness of the implementation of election supervision in Southeast Sulawesi, it can be analyzed that the greatly aspect that influences the supervision is the legal culture aspect (legal culture/public awareness aspect). Because the dominant ones who commit election violations are legislative candidates (election participants), this is evidenced by the 19 people reported from the background of election participants and the public with a campaign team segmentation of 5 (five) people, Indonesian citizens who are obliged to vote for 13 (thirteen) people, ASN 2 (two) people, officials 5 (five) people and apparatus 3 (three) people as well as the segmentation of election organizers who became reported as many as 10 (ten) people. 
After analyzing the findings and existing reports, it was found that 2 factors caused the massive violations, including that the reported party's unconsciousness that it qualifies as a violation and the reported lack of awareness in implementing direct, general, free, confidential, honest and fair in the administration of elections. From the aspect of legal culture, the general public or the parties misunderstand that their actions are classified as violation in election.

The Bawaslu of Southeast Sulawesi Province has carried out an effective function in adjudicating the resolution of election disputes effectively because the Bawaslu of Southeast Sulawesi Province has examined and decided 4 process disputes until the final verdict where the applications submitted to the Bawaslu of Southeast Sulawesi Province have met the formal and material requirements specified in the regulations of election supervisory Agency on dispute resolution of the election process. In handling administrative violations, Bawaslu Southeast Sulawesi Province has handled 5 (five) administrative violations with ineligible formil and materil verdicts, 2 (two) administrative violations with a verdict not proven legally and a verdict proven legally. This achievement is an effective performance of making verdicts that lead to doing things right, which contributes to fulfill mission or achieve goals of agency. ${ }^{12}$ Permata Wesha's view on effectiveness said that effectiveness is the state or ability of the success of a work done by humans to provide the expected benefits. In other words, in the process of handling the violation, the indicators of program success, target success, satisfaction with the program, input and output levels, achievement of overall objectives.

\section{Conclusion}

Based on the results of the role of the Southeast Sulawesi Bawaslu in Supervision of the 2019 Election and the effectiveness of the implementation of Article 461 paragraph 6 and Article 464 of Law Number 7 of 2017 concerning administrative violations of the 2019 Election in Southeast Sulawesi, it can be concluded that:

1. The role of the Southeast Sulawesi Bawaslu in Supervision of the 2019 Election is in accordance with the 1945 Constitution of the Republic of

${ }^{12}$ Amin Tunggal Widjaya, 1993, Manajemen suatu pengantar cetakan pertama, Rineka Cipta Jaya, Jakarta, p. 32. 
Indonesia and the rules of election law in this case according to Law Number 7 of 2017 concerning General Elections. In addition, the Southeast Sulawesi Province Bawaslu has also carried out violations prevention functions by increasing community/public participation through participatory election monitoring programs that involve voters to coorperate with Bawaslu in overseeing the election process. Bawaslu of Southeast Sulawesi Province has also found 121 findings of alleged election violations, the implementation of the authority to adjudicate election disputes in this case administrative violations of the election and election process disputes, Bawaslu based on the aim of realizing the direct, general, free, confidential, honest and fair, the Bawaslu of Southeast Sulawesi Province has carried out this function optimally.

2. Bawaslu of Southeast Sulawesi Province reflects the effectiveness of the implementation of Article 461 paragraph 6 and Article 464 of Law Number 7 of 2017 concerning General Elections related to sanctions for administrative violations of the 2019 General Election in Southeast Sulawesi. The Bawaslu of Southeast Sulawesi Province has handled 5 (five) administrative violations with verdicts that do not meet the formal and material requirements, 2 (two) administrative violations with a verdict not proven legally and a verdict proven legally. This achievement is an effective performance of making verdict that lead to doing things right, which contributes to fulfill mission or achieve goals of agency. The violation was caused by the reported party's unconsciousness that it qualifies as a violation and the reported lack of awareness in implementing direct, general, free confidential, honest and fair in the administration of elections. From the aspect of legal culture, the general public or the parties misunderstand that their actions are classified as violation in election.

\section{References}

\section{Books}

A.Tauda, Gunawan, 2012, Komisi Negara Independen (Eksistensi Independent Agencies sebagai Cabang Kekuasaan Baru dalam Sistem Ketatanegaraan), Genta Press, Yogyakarta.

Asshiddiqie, Jimly, 1956, Teori \& Aliran Penafsiran Hukum Tata Negara, Ind. Hill.Co, Jakarta.

Darumurti, Krishna D. dan Umbu Rauta, 2003, Otonomi Daerah Perkembangan Pemikiran, Pengaturan dan Pelaksanaan, Citra Aditya Bhakti, Bandung. 
Fachrudin, Achmad, 2013, Jalan Terjal Munuju Pemilu 2014: Mengawasi Pemilu Memperkuat Demokrasi, Gramedia Utama Publishindo, Jakarta.

Harahap, M. Yahya, 2007, Ruang Lingkup Permasalahan Eksekusi Bidang Perdata, Sinar Grafika, Jakarta.

Husein, Harun, 2014, Pemilu Indonesia: Fakta, Angka, Analis, dan Studi Banding, Perludem, Jakarta.

Makarao, Moh. Taufik, 2004, Pokok - Pokok Hukum Acara Perdata, Cet. 1, PT. Rineka Raya, Jakarta.

Marzuki, Peter Mahmud, 2005, Penelitian Hukum, Kencana Prenada Media Group, Jakarta.

Meny, Yves dan Andrew Knapp, 1998, Government and Politic in Western Europe: Britain, France, Italy, Germany, 3rd edition, Oxford University Press, Oxford.

Mertokusumo, Sudikno, 1998, Hukum Acara Perdata Indonesia, Liberty, Yogyakarta.

Sarwoto, 1990, Dasar - Dasar Organisasi dan Manegemen, Ghala Indonesia, Jakarta.

Subekti, R, 1989, Hukum Acara Perdata, Cet. 3, Nina Cipta, Bandung.

Supriatno, 1993, Administrasi Pembangunan Daerah, Raja Grafindo Persada, Jakarta.

Widjaya, Amin Tunggal, 1993, Manajemen Suatu Pengantar, Cet. 1, Rineka Cipta Jaya, Jakarta.

\section{Journal}

Ackerman, Bruce, "The New Separation of Powers", The Harvard Law Review, Vol. 113, HVLR 633, January 2000.

Jazuli, Syukron, "Independent Agencies dalam Struktur Ketatanegaraan Republik Indonesia", Supremasi Hukum: Jurnal Kajian Ilmu Hukum, Vol. 4, No. 1, June 2015.

Wahid, Abdul, "Meneguhkan Bawaslu sebagai Lembaga Peradilan dalam Bingkai Pengawasan Pemilu", Jurnal Adhyasta Pemilu, Vol. 4, No. 1, 2018. 